\title{
GLASS-MAKING MATERIALS.
}

During the last season several important glass-manufacturing districts have been visited by Survey geologisis, and careful investigation has been made of the glass sands and other raw materials used in the manufacture of this product. The results of this work are summarized in the following three reports:

\section{THE REQUIREMENTS OF SAND AND LIMESTONE FOR GLASS MAKING.}

By Ernest F. Burchard.

\section{INTRODUCTORY STATEMENT.}

The data for the following paper were derived from a brief study of the glass sands of the middle Mississippi basin. Glass manufacture admits of such slight variations in the character of its raw materials that the materials used from the Central States are regarded as representing very fairly the grade demanded for the industry at large. The points considered in this paper are intended mainly to serve as a guide to persons who wish to know whether certain sandstones or limestones may be suitable for glass making Therefore only the chemical and physical p:o zerties are taken up here, and the consideration of other conditions on which the value of a deposit depends is reserved for the paper "Glass sands of the middle Mississippi basin," pages 459-472 of this bulletin.

is

\section{LITERATURE.}

The statistics of the production of glass sand in 1902, 1903, and 1904 have been gathered and compile 1 N. T. Coons and published each year by the Survey in "Mireral Resources of the Unif States." These reports have been freely used in preparing papers for this bulletin. Besides these reports there is not much literature dealing diractly with glass sand, but nearly all technical papers or manuals on the subject of glass contain useful data with regard to the sand. Among such technical papers may be mentioned the following:

WEEks, J. D., Glass materials: Mineral Resources U. S. for 1883-84, U. S. Geol. Survey, 1885.

BisER, B.F., Elements of Glass and Glass Making, 1899.

Linton, RosnRT, Glass Making in the United States: Eng. and Min. Jour., vol.68, No. 16, 1899, p. 454. Linton, Robert, Glass: Mineral Industry for 1899, 1900, pp. 234-263.

Gillinder, JAmES, Glass Manufactures in Ameriea: Eneyclopedia Americana, vol. 8.

AUstin, Shirley P., Glass: Twelfth Census of the United States, vol. 9, Monufactures, pt. 3, 1902, pp. 941-1000.

UhLiG, E. C., Chemical Analysis for Glass Makers, 1903.

GRimsLey, G. P., Manufacture of glass in Kansas: First biennial report Kansas Bureau of Labor. 1901-2, 1903, pp. 343-346. 


\section{DEFINITION AND COMPONENTS OF GLASS.}

Glass is a fused mixture of the silicates of alkalies, alkaline earths, and of more common metals. Usually the alkaline bases are sodium and potassium; the alkaline earth is calcium, and the common metallic element is lead. All of these are used in the form of salts. In melting together the various ingredients employed in the batch or mixture it appears that silica under the influence of heat in the presence of a flux forms silieates with sodium or potassium, and calcium, lead, etc., and the alkaline silicate then dissolves the remaining silicates. It is this solution that solidifies into glass on cooling. Glass may be divided into four general classes - plate, window, green bottle, and flint. Owing to manufacturing conditions, few makers follow the same formula, but the following table shows the general proportion by weight which sand bears to the other ingredients commonly used in certain types of American-made glass. $a$

General proportions by weight of various components of glass.

\begin{tabular}{|c|c|c|c|c|c|}
\hline Component. & $\begin{array}{l}\text { Plate } \\
\text { glass. }\end{array}$ & $\begin{array}{l}\text { Window } \\
\text { glass. }\end{array}$ & $\begin{array}{l}\text { Green } \\
\text { bottle. }\end{array}$ & $\begin{array}{l}\text { Lead } \\
\text { flint. }\end{array}$ & $\begin{array}{l}\text { Lime } \\
\text { flint. }\end{array}$ \\
\hline Sand $\left(\mathrm{SiO}_{2}\right) \ldots$ & 100 & 100 & 100 & 100 & 100 \\
\hline Salt cake $\left(\mathrm{Na}_{2} \mathrm{SO}_{4}\right) \ldots$ & -... & 42 & 38 & & -... \\
\hline Soda ash $\left(\mathrm{Na}_{2} \mathrm{CO}_{3}\right) \ldots$. & 36 & $\cdots$ & .... & . & 36 \\
\hline Limestone $\left(\mathrm{CaCO}_{3}\right) \ldots \ldots \ldots$ & 24 & 40 & 34 & -.. & .... \\
\hline Carbon (C) ............. & .75 & 6 & 5 & & \\
\hline Arsenie $\left(\mathrm{As}_{2} \mathrm{O}_{3}\right) \ldots \ldots$. & 1 & 2 & & .15 & .02 \\
\hline Slaked lime $\left(\mathrm{Ca}(\mathrm{OH})_{2}\right) \ldots$ & & & & $\cdots$ & 12 \\
\hline Potash $\left(\mathrm{K}_{2} \mathrm{CO}_{3}\right) \ldots \ldots \ldots \ldots \ldots$ & 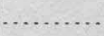 & $\ldots$ & & 34 & \\
\hline Red lead $\left(2 \mathrm{PbO}+\cdot \mathrm{PbO}_{2}\right) \ldots$ & & & & 48 & \\
\hline Niter $\left(\mathrm{NaNO}_{3}\right) \ldots \ldots . .$. & .. & $\cdots$ & & 6 & 1 \\
\hline Manganese $\left(\mathrm{MnO}_{2}\right) \ldots$ & & & & .06 & 6.66 \\
\hline Antimony (Sb).... & & & & .02 & $\ldots 23$ \\
\hline
\end{tabular}

Sand is therefore the major constituent of glass, constituting from 52 to 65 per cent of the mass of the original mixture; or from 60 to 75 per cent of the finished product after melting has driven off carbon dioxide, sulphur dioxide, and other volatile materials. To the sand is due the absence of color (according to its purity), the Gensparency, brilliancy, and hardness of glass. In other words, the quality of the glass depends largely on the quality of the sand. For the finest flint ware, such as optical and alt glass, "water whiteness," absolute transparency, great brilliance, and uniform density are required, and only the purest sand can be employed, since slight impurities, especially small quantities of iron, tend to destroy these effects. For plate and window glass, which are-commonly pale green, absolute purity is not so essential, but generally the sand shoule mot carry more than two-tenths per cent of ferric oxide. Green and amber glass for bottles, Jais, and rough structural work ean be made from sand relatively high in impurities. An excess of the chief impurity, iron, is usually avoided in the quarries by a careful selection of the whitest sand, although the whitest sand is not invariably the purest. Repeated washing tends to remove the iron. Magnetic separators also have been resorted to, especially when the iron is present in the form of magnetite. Clay materials are objectionable because they cloud the glass. Washing helps to remove them, since they occur usually in a very finely divided state. Magnesia, which is more apt to be introduced into glass matterials through

a Data, except for lime flint, are taken from Linton, Robert, Glass: Mineral Industry for 1899, vol 8, 1900, pp. 244-245. 
limestone than through sand, is troublesome because it renders the batch less fusible. If the sand is derived from indurated sandstone the latter should be friable or easily crushed. In examining sand, in order to ascertain its value for glass-making purposes, inspection with a magnifying glass is the best preliminary test. The following points should be observed: The sand should be nearly white in color; it should be of medium fineness (passing a 20 to 50 mesh horizontal sieve); the grains should be uniform in size, even, and angular, or, less preferably, they may be rounded. A simple chemical test may be employed by heating the sand in a dilute acid. Effervescence indicates the presence of lime; loss of color shows the presence of clay impurities. Iron in the most minute quantity may be detected by dissolving sand in hydrofluoric acid and adding potassium ferrocyanide, which produces a blue precipitate if iron is present. Complete quantitative analyses as well as a furnace test should be made as a final determination of the character of a prospective glass sand. The impression has long prevailed, especially among writers on the subject of glass making, that round-grained sands are at a decided disadvantage in comparison with the sharp, angular variety. Practice seems to disagree with this idea, at least in the case of the Mississippi Valley plants, where smooth, rounded sand is successfully used for all ordinary varieties of glass and for some fine flint ware. As a rule, no very close check is kept on materials by manufacturers of the ordinary commercial grades of glass. Results are watched with care, however, and experience with certain materials usually determines their use or rejection. Sand uniformly finer than one-sixtieth inch is said to "burn out" in the batch and not to produce as much glass per unit of weight as does coarser sand. In a mixture of coarse and fine sand the finer sand is liable to settle to the bottom of the batch, thus preventing an even mixture of the materials and producing in consequence a glass uneven in texture.

\section{ANALYSES OF GLASS SAND.}

The following analyses submitted by the American Window Glass Company show the different qualities of sand used in its glass works:

Analyses of glass sand used by American Window Glass Company.

\begin{tabular}{|c|c|c|c|c|}
\hline Constituent. & No. 1. & No. 2. & No. 3. & No. 4. \\
\hline Silica $\left(\mathrm{SiO}_{2}\right) \ldots \ldots \ldots \ldots \ldots$ & 99.990 & 99.714 & 99.659 & 99.579 \\
\hline Alumina $\left(\mathrm{Al}_{2} \mathrm{O}_{3}\right) \ldots \ldots \ldots \ldots \ldots \ldots \ldots \ldots$ & .008 & .280 & .310 & .350 \\
\hline Iron oxide $\left(\mathrm{Fe}_{2} \mathrm{O}_{3}\right) \ldots \ldots \ldots \ldots \ldots \ldots$ & $\underset{\text { trace. }}{\text { Slight }}$ & .006 & .011 & .021 \\
\hline \multirow[t]{2}{*}{ Lime and magnesia $(\mathrm{CaO}$ and $\mathrm{MgO}) \ldots \ldots \ldots \ldots \ldots \ldots \ldots \ldots$} & .002 & .020 & .020 & .050 \\
\hline & 100.000 & 100.020 & 100.000 & 100.000 \\
\hline
\end{tabular}

No. 1 is suitable for the very highest grades of glassware and flint glass. Nos. 2 and 3 are suitable for tableware, plate glass, chimneys, prescription ware, etc., and No. 4 is used for window glass.

The following analyses are submitted by the Pittsburg Plate Glass Company as samples of sand used by its plants: 
Analyses of glass sañd used by Pittsburg Plate Glass Company.

\begin{tabular}{|c|c|c|c|c|}
\hline Constituent. & No. 1. & No. 2. & No. 3. & No. 4. \\
\hline Silica $\left(\mathrm{SiO}_{2}\right) \ldots \ldots \ldots$. & 99.21 & 98.90 & 98.95 & 98.94 \\
\hline Alumina $\left(\mathrm{Al}_{2} \mathrm{O}_{3}\right) \ldots \ldots \ldots \ldots \ldots$ & .30 & .20 & .50 & .30 \\
\hline Volatile matter ......... & .21 & .25 & .24 & .23 \\
\hline Iron oxide $\left(\mathrm{Fe}_{2} \mathrm{O}_{3}\right) \ldots$ & .003 & .002 & .0024 & .0036 \\
\hline Linie $(\mathrm{CaO}) \ldots \ldots \ldots$ & .20 & .54 & .30 & .40 \\
\hline \multirow{2}{*}{ 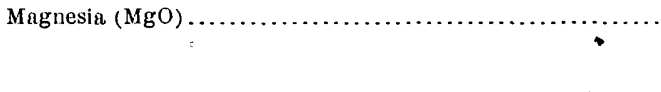 } & 'Trace. & .20 & .10 & Trace. \\
\hline & 99.923 & 100.092 & 100.0924 & 99.8736 \\
\hline
\end{tabular}

For sands with analyses comparable with the above, no decolorization is attempted in manufacturing plate glass. Sand containing more iron than is shown in the tables may be used in making green glass bottles and cheap glassware, or, with the addition of decolorizing agents, in making window glass. 
Analyses of glass sands mined

\begin{tabular}{|c|c|c|c|c|}
\hline \multirow{2}{*}{ Location of mine or quarry. } & \multirow[b]{2}{*}{ Operator. } & \multicolumn{3}{|c|}{ Constituent. } \\
\hline & & $\begin{array}{l}\text { Silica } \\
\left(\mathrm{SiO}_{2}\right) \text {. }\end{array}$ & $\mid \begin{array}{c}\text { Magnesia } \\
(\mathrm{MgO}) .\end{array}$ & $\begin{array}{l}\text { Lime } \\
(\mathrm{CaO}) .\end{array}$ \\
\hline ILLINOIS. & & & & \\
\hline Ottawa, Lasalle County. & Ottawa Silica Co.. & 99.45 & Trace. & 、 0.13 \\
\hline South Ottawa, Lasalle County.. & United States Silica Co..... & 99.89 & 0.01 & .00 \\
\hline Wedron, Lasalle County. . & Wedron White Sand Co... & 99.89 & .01 & .00 \\
\hline Utica, Lasalle County.... & I. J. Reynolds \& Co....... & 99.576 & 002 & .0197 \\
\hline MISSOURI. & & & & \\
\hline Klondike, St. Charles County... & Tavern Rock Sand Co...... & 99.97 & & \\
\hline Grays Summit, Franklin County. & White Sand Co. of Missouri. & 99.839 & & \\
\hline Jefferson County, near Pacific...... & Missouri Silica Co.......... & 99.69 & .3 & \\
\hline
\end{tabular}

Physical properties of glass sands,

\begin{tabular}{|c|c|c|c|}
\hline Locality. & Operator. & Sample. & Color. \\
\hline Ottawa, Ill. & Ottawa Silica Co. & Finest grained... & Very faint yellow. \\
\hline Do. & .....do. . & Fine and coarse mixed. & White.. \\
\hline Do.. & .....do.. & Coarsest grained.. & .....do....... \\
\hline Do.. & ....do....... & Crude, direct from pit. . & Grayish white... \\
\hline Utica, Ill. . & E. J. Reynolds \& Co.. & Crude, from car..... & Grayish ycllow.. \\
\hline Klondike, Mo. & 'Tavern Rock Sand Co. & Extra quality......... & White........ \\
\hline Do.. & ....do... & Average quality........ & Faint pinkish yellow. \\
\hline Do.. & .....do...... & Crude, direct from pit... & White............... \\
\hline Grays Summit, Mo. & White Sand Co. of Missouri. & Finished product.. & .....do.... \\
\hline Do.. & .....do........... & Crude, from quarry ..... & Very light gray ..... \\
\hline Pacific, Mo. & Pacific White Sand Co.. & Finished product....... & Faint pinkish white. \\
\hline Do.. & Missouri Silica Co..... & Direct from quarry.... & Faint yellow . . . . . . . . \\
\hline Do... & Pacific Glass Sand Co....... & Prepared for plate glass. & Paint yellowish white \\
\hline Do.. & ......do....... & Dried, not screened.... & Faint yellow... \\
\hline Do... & .....do............ & Crude, mine run....... & ....do........ \\
\hline Crystal City, Mo. & Pittsburg Plate Glass Co.. & Prepared.. & $\ldots$..do....... \\
\hline Do... & .....do.............. & A verage mine run.... & $\begin{array}{l}\text { White, with faint yel- } \\
\text { low lumps. }\end{array}$ \\
\hline $\begin{array}{l}\text { Berkeley Springs, w. } \\
\text { Va. }\end{array}$ & West Virginia Sand Co... & $\begin{array}{l}\text { Crushed sandstone, fin- } \\
\text { ished product. }\end{array}$ & Grayish white....... \\
\hline
\end{tabular}


in the Mississippi basin.

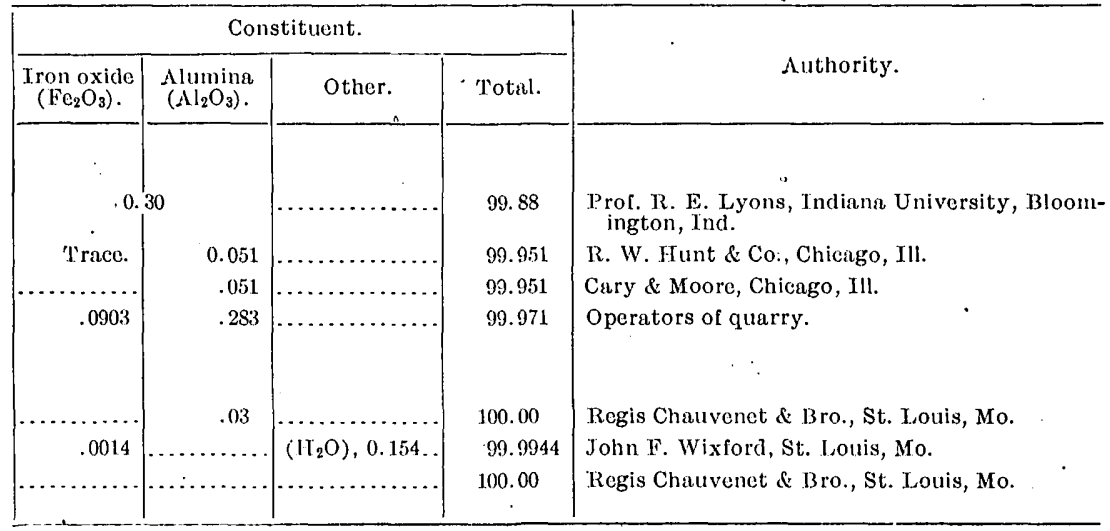

mainly from middle Mississippi basin.

\begin{tabular}{|c|c|c|c|c|c|}
\hline \multirow[b]{2}{*}{ Angularity. } & \multicolumn{5}{|c|}{ Sieve tests (percentuges are approximate). } \\
\hline & Larger than 20 mesh. & $\begin{array}{c}\text { P'asses } \\
20 \text { mesh." }\end{array}$ & $\begin{array}{l}\text { Passes } \\
40 \text { mesh. }\end{array}$ & $\begin{array}{l}\text { Passes } \\
60 \text { mosh. }\end{array}$ & $\begin{array}{c}\text { l'nsses } \\
100 \text { mesh. }\end{array}$ \\
\hline very little... & $\cdots$ & 100 & 100 & 92 & 25 \\
\hline .....do... & A few grains.... & $99+$ & 85 & 18 & 3 \\
\hline None........ & 1 per cent.............. & 99 & 6 & $1-$ & 0 \\
\hline .....do.... & $\Lambda$ few grains....... & $99+$ & 23 & 3 & $1-$ \\
\hline Very litile.. & ....do. ................ & $99+$ & $4 \pi$ & 11. & 3 \\
\hline ....do.... & Small lumps only ..... & 100 & 90 & 15 & 1 \\
\hline ....do..... & Fine lumps only ......... & 100 & 82 & 17 & 2 \\
\hline None............ & - $\ldots \ldots \ldots$ & 100 & 90 & 15 & 1 \\
\hline Very little.. & ...... & 100 & 92 & 25 & 2 \\
\hline .... do...... & Fine lumps only ...... & 100 & 88 & 55 & $1-$ \\
\hline None........... & Small lumps only ........ & 100 & 85 & 12 & 2 \\
\hline .... do..... & ....do................. & 100 & 96 & 42 & 2 \\
\hline A little of finest grair & ………… & 100 & 99 & 60 & 10 \\
\hline None................. & Small lumps............ & 100 & 90 & 22 & 2 \\
\hline Very little... & $\ldots \ldots$ do $\ldots \ldots \ldots \ldots \ldots \ldots$ & 100 & 85 & 65 & 5 \\
\hline ..... do....... & Less than 1 per cent..... & $99+$ & 23 & 13 & 1 \\
\hline None....... & ... & 100 & 55 & 20 & 1 \\
\hline 90 per oent. & & 100 & 98 & 25 & $1-$ \\
\hline
\end{tabular}




\section{REQUIREMENTS OF LIMESTONE.}

In its connection with sand as a glass material limestone is of interest to quarrymen. As shown in the table on page 453, limestone enters the batch of several kinds of glass to the extent of about 18 per cent of its mass. The rock is crushed, ground finely, and screened. Purity is as essential in limestone as in sand, and it is probable that much of the impurity which finds its way into the batch comes unsuspectedly from the limestone. Limestone, therefore, should be analyzed frequently, as it may carry clay anci iron pyrites as well as carbonates of iron and magnesia, all of which are objectionable for reasons previously stated. Moreover, beds in the same quarry often vary in composition within short distances. Lim, stone of good quality belonging mainly to the Carboniferous system is widely distributed in Illinois, Missouri, Kansas, and other central glass-manufacturing States, and, compared with sand, it brings a high price. Analyses of certain limestones used in this industry are given below, and many suitable limestones are described by $\mathrm{Mr}$. E. C. Eckel in Bulletin No. 243, on the Cement Materials and Industry of the United States.

Analyses of limestone used in glass making.

\begin{tabular}{|c|c|c|c|c|c|}
\hline Locality. & $\begin{array}{c}\text { Lime car- } \\
\text { bonate } \\
\text { (CaCos). }\end{array}$ & $\begin{array}{c}\text { Magne- } \\
\text { sium car- } \\
\text { bonate } \\
\left(\mathrm{MgCO}_{3}\right) .\end{array}$ & $\begin{array}{c}\text { Iron oxide } \\
\left(\mathrm{Fe}_{2} \mathrm{O}_{3}\right)\end{array}$ & $\begin{array}{l}\text { Alumina } \\
\left(\mathrm{A} 1_{2} \mathrm{O}_{3}\right)\end{array}$ & $\begin{array}{c}\text { Silicates } \\
\text { and silica } \\
\left(\mathrm{SiO}_{2}\right) .\end{array}$ \\
\hline 1. Meramec Quarry Co,. Wickes, Mo & 90.23 & 0.0 & 0.59 & & 8.87 \\
\hline 2. Meramee Quarry Co., Wickes, Mo..... & 97.96 & .18 & & & 1.86 \\
\hline 3. Armstrong Quarry, Alton, Ill.. & 97.72 & 0.0 & $\begin{array}{r}.20 \\
\left(\mathrm{Fe}_{2} \mathrm{CO}_{3 .}\right)\end{array}$ & 1.10 & 1.01 \\
\hline 4. Pennsylvania.. & 97.23 & 1.48 & .16 & .02 & 1.01 \\
\hline
\end{tabular}

1. F. P. Mason, analyst.

2. Wm. Chauvenet, analyst.

3. S. E. Swartz, analyst.

4. Min. Industry for 1899, p. 240. 


\title{
GLASS SAND OF THE MIDDLE MISSISSIPPI BASIN.
}

\author{
By Ernest F. Burchardy. \\ INTRODUCTORY STATEMENT.
}

A conservative estimate of the value of the glass products manufactured in the United States in 1905 is in round numbers $\$ 65,000,000$. The cost of material used approximates $\$ 18,000,000$, and in this the cost of glass sand was somewhat more than $\$ 1,000,000$, exclusive of freight charges. Within the half century preceding 1900 the value of glass products showed an average increase of 70 per cent for each decade, and the growth is still vigorous. In view of the remarkable development of an industry so largely dependent for its raw materials on mineral deposits, a brief study has been made of the principal sand-producing areas of the middle Mississippi basin and of their relations to manufacturing centers in the same district. Undeveloped sands in Arkansas, Missouri, Kansas, Wisconsin, and Iowa have been examined in connection with geologic surveying in progress in those States. It is hoped that the information published in this and the preceding paper may be of service to owners of land on which deposits of sand are found and to persons engaged in the production or use of glass sand who may wish to know where further supplies of the material may be obtained.

Topographic maps covering the greater part of all the areas mentioned herewith and geologic maps covering a small part of the same have been issued by the survey. Lists of these maps are given in the sections devoted to the respective areas.

In the paper "Requirements of sand and limestone for glass making," pages 452-458 of this bulletin, are outlined those characteristics which render a sand suitable or unsuitable for making glass, and in tabular form data are presented concerning the chemical composition and physical character of several sands at present in successful use. Below are given similar data regarding sands of hitherto unknown or doubtful value.

To the producer the questions of physical conditions affecting quarrying and mining, of the amount of available sand, and of location with respect to transportation routes and to markets are as important as that regarding the quality of the sand. Some details are therefore given in the descriptions of properties which illustrate conditions and limitations of successful operation.

\section{GLASS-MAKING INDUSTRY OF THE REGION.}

In connection with the examination of sand plants several representative glass factories were visited. Glass of four general classes-plate, window, green bottle, and flint- is made in the middle Mississippi basin from materials obtained, for the most part, in the region. The majority of the glass factories are grouped into two districts-the St. Louis district and the southeastern Kansas district. Fuel and raw materials are naturally the controlling factors in the location of glass plants, and of the two the proximity of fuel seems to be regarded as the more important. Where coal is the basis of the fuel, if it requires 1 ton of coal to 1 ton of glass, nearly as much coal by weight as raw material has to be transported, yej the freight rates on sand, lime, and salt cake are decidedly higher than on coal for a given 
distance. Therefore, it is important that plants using coal should also be relatively near a supply of sand. When natural gas in a fresh field is the fuel it is so much cheaper than producer gas made from coal near the mines that the glass can stand the cost of a long haul for sand and other materials if necessary.

St. Louis district.-About eight factories are situated in this district-two at St. Louis, one at Valley Park, and one at Crystal City, Mo., and one each at East St. Louis, Belleville, Alton, and Litchfield, Ill. The factories in St. Louis itself are situated well between the sand; 35 miles or more to the west, and the Illinois coal fields 10 to 15 niles to the east. The other factories range in location from the one situated on the glass sand at Crystal City to the one situated on the coal at Belleville. Producer gas from southern Illinois coal is commonly employed as fuel, although one furnace at Alton is fired direct, from coal. Plate glass is made by Pittsburg firms at Crystal City and at Valley Park. The factory at Crystal City has been established about thirty years. Its present capacity is two furnaces of 20 pots each. A new pot house is under construction, and other new buildings of a value of $\$ 2,000,000$ are under contract. The factory at Valley Park has been erected within the last few years. It contains four furnaces of 20 pots each.

The main products of the other factories are bottles of various grades, certain ones making beer bottles exclusively. The plant at Alton, said to be the largest in the United States, makes bottles of every description, besides miscellaneous articles from both common and flint glass. Eight glass houses are operated at Alton, both the pot and the continuous-tank systems being employed.

Southeastern Kansas district.-The manufacture of glass in the Kansas gas belt was begun less than three years ago. There are now 21 plants in the field, including one just across the line at Bartlesville, Ind. T., all using natural gas for fuel. These glass factories are located as follows: Coffeyville 7, Independence 3, Peru 2, Chanute 2, Altoona 2, Cancy, Cherryvale, Neodesha, Fredonia, and Bartlesville 1 each. Many of them have been moved from the waning gas fields of Indiana, attracted by the cheapness and abundance of gas in the new field. Whereas the cost of producer gas or of gas made from oil in the St. L.ouis district, and in Indiana and Pennsylvania, is from 8 to 12 cents per thousand cubic feet, Kansas manufacturers are paying only 3 cents per thousand for natural gas and some plants are said to obtain it as low as 2 cents. No plate glass is made in this field at present, but practically all the other grades of window glass and all the wares of glass except the finest material for chemical and optical purposes are made.

A run of glass was made in 1903 at the works of the Midland Glass Company at Independence under the direction of Superintendent Thornberg. Kunsas materials were used, including sand from the Buxton formation near Fredonia (corresponding to samples 1. and 2, p. 462), limestone from Sedan, and salt cake from the sulphuric-acid works at Argentine. The glass was clear and of high quality, and the character of the materials seemed to be all that could be desired. Interest in the development of this glass sand has been revived recently and it may be opened up if the project can be placed on a practicable basis. At Coffeyville three plants make window glass, and certain of the others make bottles, fruit jars, table ware, and lantern chimneys. All three plants at Independence and the plant at Fredonia make window glass. The plant at Caney makes a variety of wares. That at Cherryvale makes a special feature of tumblers and table ware, using an excellent grade of clear lead-flint glass. At Neodesha flasks and prcscription bottles of flint glass are made. Sand is supplied mostly from the belt west of St. Louis, and the freight charges bring the total cost of material per ton to about four times its selling price. $A$ little sand has been imported from the Ottawa, Ill., district at a total cost per ton of nearly eight times its selling price. In regard to limestone supplies the Kansas factorics are situated more advantageously. Some crushed limestone has been obtained from neighboring cement mills and considerable is shipped from Sedan. Still it seems to be necessary to import the greater portion of it from Missouri points, Ash Grove being an important center. Salt cake is brought from Argentine, Kans., and the Kansas plants are thus nearer to this important requisite than any others except one located at Kansas City. The first plants erected in southeastern Kansas 
were pot furnaces, but of the more recent ones nearly all are continuous-tank furnaces. The continuous-tank system, while involving a nuch greater initial expense, is estimated to increase the output about 40 per cent over that of the pot furnace with the same amount of fuel and labor, besides producing a more uniform quality of glass. At Cofieyville fruit jars are blown with compressed air by a system of automatic blowpipes and molds.

\section{LOCAL PRODUCTION AND METHODS OF PREPARATION OF SAND.}

Illinois and Missouri together furnish at present about 350,000 short tons annually, nearly 40 per cent of the total supply of glass sand in the United States. Pennsylvania produces atout 33 per cent, and therefore ranks first in quantity of this product, with Illinois second and Missouri third. According to the latest complete statistics (for 1905) the average value of glass sand per ton in Pennsylvania was $\$ 1.31$, in Illinois 63 cents, and in Missouri 60 cents. This notable difference in prices between Pennsylvania and western sand is accounted for in part by the fact that Pennsylvania sand is somewhat more expensive to produce, being made from harder rock. A sharper, even-grained, and consequently a slightly more desirable glass sand is the result. Pennsylvania, West Virginia, and Maryland sands, all sold at a high price, are consumed for the most part within those States, and the importation of western sand would be expensive. Therefore prices are largely controlled by the cost of western sands plus freight charges. In the Mississippi Valley glass sand is produced principally from the Fox River district in north-central Illinois, near Ottawa, and from Missouri just west of St. Louis. These sands, besides supplying a large local demand, are shipped to all points within a radius of 500 miles, and frequently to a greater distance. Silica for other purposes, such as steel castings, linings of acid converters, fire brick, etc., is regularly shipped to Pacific coast points-Portland, Tacoma, and San Francisco.

The prepairation of glasss sand has become a highly specialized business, and in the middle Mississippi Valley 1.5 or more thoroughly equipped plants are at present employed. The large investments in sand properties and mills have developed very active competition between these establishments, and this competition has resulted in great care in the preparation of glass sand and in a high-grade product. Besides glass sand almost an ëqual quantity of other sand is produced at these plants for various purposes, such as molding, furnace lining, stone sawing, grinding plate glass, and glazing pottery. Most of this sand requires less care in selection and preparation, yet it brings almost as high a price as glass sand and therefore yields more profit.

The method of treatment of glass sand depends on the character of the deposit and on its position. Some beds of sandstone are so friable and pure that only blasting down and slight crushing are necessary before the sand is dried and screened. Many plants, however, wash their sand in course of preparation, particularly those in Illinois, where hydraulicking is employed to obtain sand from the quarries. Washing doubtless removes, even from high-grade sand, considerable silica in such a fine state as to be detrimental, as well as an appreciable quantity of undesirable impurity, mainly clay, as is indicated by the following analysis of slime from washings of sand at Ottawa:

\section{Analysis of slime from washings of Ottawa, Ill., sand.}

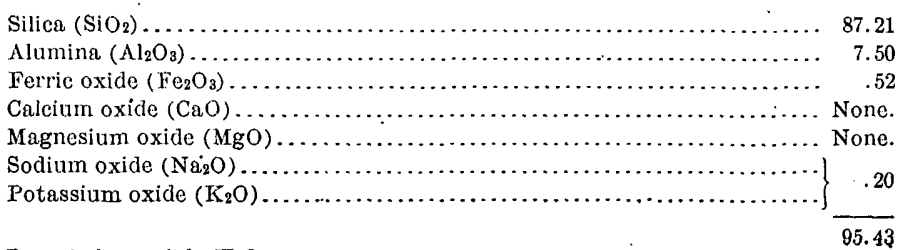

Remainder mainly $\mathrm{H}_{2} \mathrm{O}$.

Bụll, 285-06--30 
Partial analyses of sands from Mississippi

[Analyst, George Steig $\checkmark r$, United

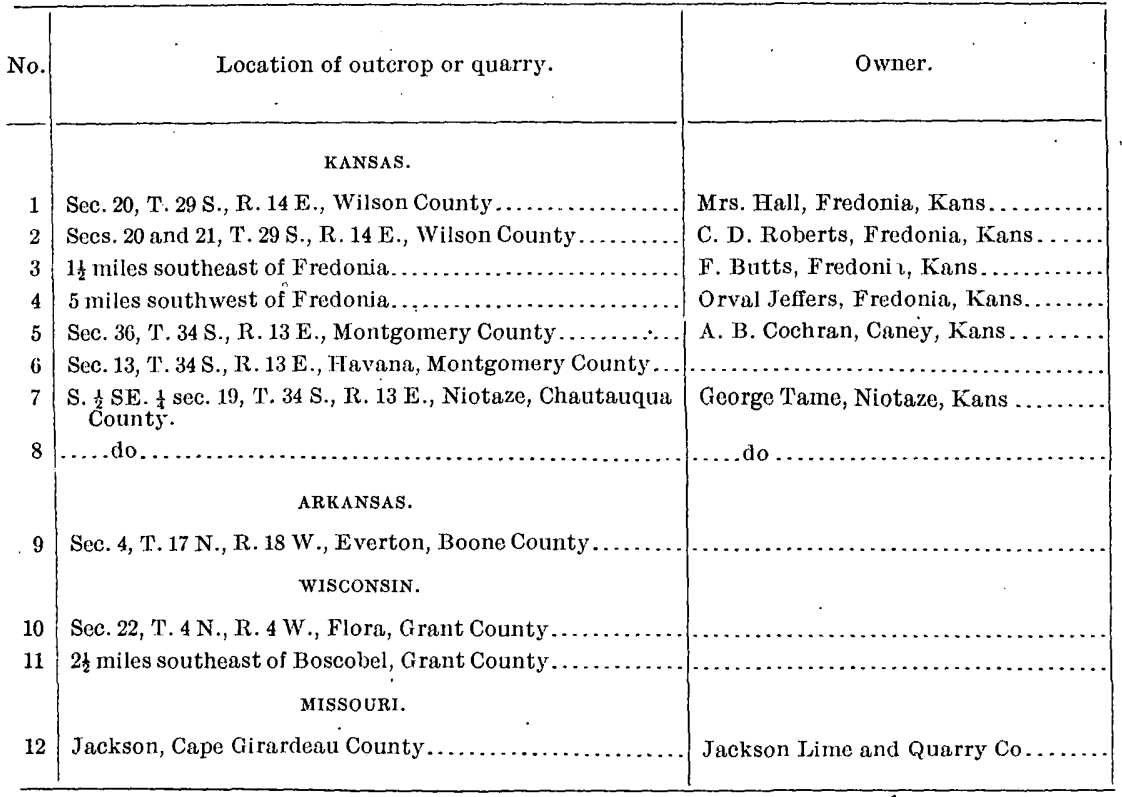

Physical properties of sands of

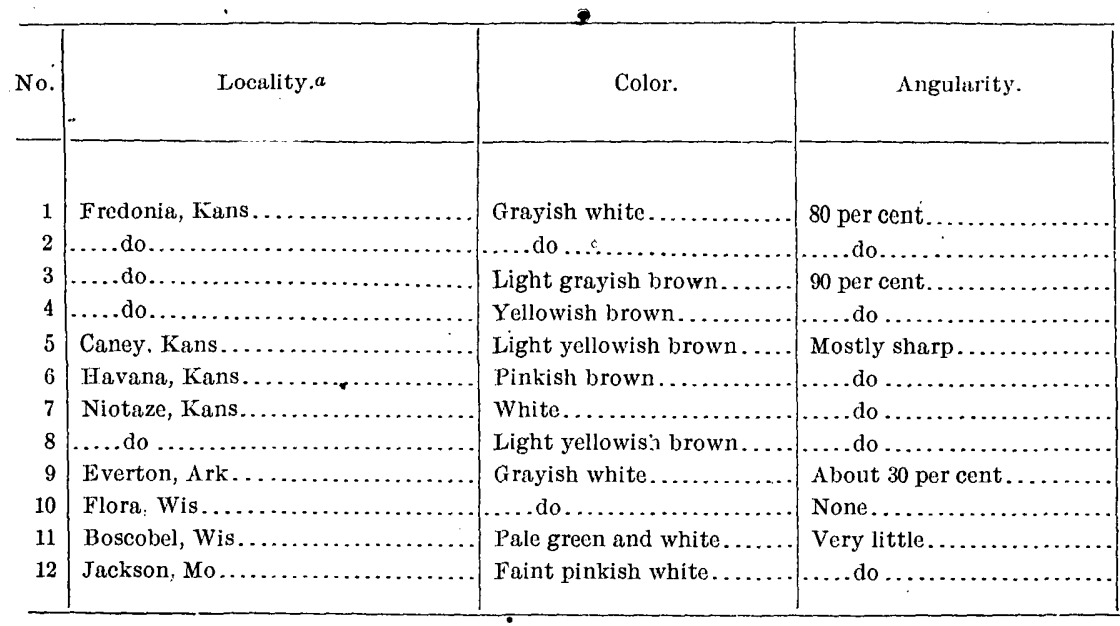

$a$ See preceding table for township, section, etc. 
basin of possible value for glass making.

States Geological Survey.]

\begin{tabular}{|c|c|c|c|c|c|}
\hline \multicolumn{6}{|c|}{ Constituent. } \\
\hline Silica $\left(\mathrm{SiO}_{2}\right)$ & Magnesia (MgO) & Lime $(\mathrm{CaO})$. & $\begin{array}{l}\text { Oxide of iron } \\
\left(\mathrm{Fe}_{2} \mathrm{O}_{3}\right)\end{array}$ & $\begin{array}{c}\text { Aluminina } \\
\left(\mathrm{Al}_{2} \mathrm{O}_{8}\right) .\end{array}$ & 'J'otal. \\
\hline Per cent. & Per cent. & Per cent. & Per cent. & Per cent. & Per cent. \\
\hline 97.59 & & & 0.33 & :...... & 97.92 \\
\hline 98.00 & 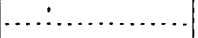 & $\cdots \cdots$ & .37 & $\cdots \cdots$ & 98.37 \\
\hline 97.50 & .. & 0.10 & .43 & 1.62 & 99.65 \\
\hline 97.84 & 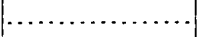 & & .63 & .... & 98.57 \\
\hline 97.08 & . & $\ldots$ & .72 & $\ldots$ & 97.80 \\
\hline 97.80 &. &. & .84 & ...... & 98.64 \\
\hline 96.45 & & & .37 & 2.76 & 99.58 \\
\hline 96.90 & $\ldots$ & & .67 & 2.03 & 99.60 \\
\hline 99.55 & & & .09 & .13 & 95.77 \\
\hline 99.17 & & & .22 & .25 & 99.64 \\
\hline 99.47 & & & .07 & $\ldots \ldots \ldots \ldots \ldots$ & 99.54 \\
\hline 99.52 & & & .07 & .16 & 99.75 \\
\hline
\end{tabular}

possible value for glass making.

\begin{tabular}{|c|c|c|c|c|}
\hline \multicolumn{5}{|c|}{ Sieve tests. (Percentages are approximate.) } \\
\hline Larger than 20 mesh. & $\begin{array}{l}\text { Passes } \\
20 \text { mesh. }\end{array}$ & $\begin{array}{r}\text { Passes } \\
40 \text { mesh. }\end{array}$ & $\begin{array}{l}\text { Passes } \\
60 \text { mesh. }\end{array}$ & $\begin{array}{c}\text { Passes } \\
100 \text { mesh. }\end{array}$ \\
\hline & Per cent. & Per cent. & Per cent. & Per cent. \\
\hline 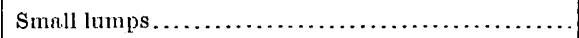 & 100 & 99 & 60 & 15 \\
\hline$\ldots \ldots$ do $\ldots \ldots \ldots \ldots . . .$. & 100 & 100 & 65 & 20 \\
\hline$\ldots$. do..... . & 100 & 85 & 35 & 10 \\
\hline .....do........ & 100 & 80 & 60 & 15 \\
\hline$\ldots \ldots \ldots \ldots \ldots$ & 100 & 100 & 95 & 35 \\
\hline Few sinall lumps. . . . . . . . . & 100 & 100 & 80 & 20 \\
\hline 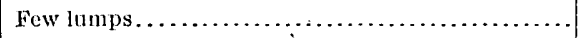 & 100 & 100 & 100 & 90 \\
\hline$\ldots \ldots$ do $\ldots \ldots \ldots \ldots \ldots \ldots \ldots \ldots \ldots$ & 100 & $1 \mathrm{CO}$ & 90 & 50 \\
\hline 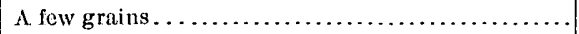 & $99+$ & 97 & 50 & 10 \\
\hline$\ldots$ do $\ldots . . . \ldots . . .$. & $99+$ & 80 & 40 & 15 \\
\hline $1+$ per cent. . . . . . . . . & $98+$ & $\cdot 35$ & G & $1-$ \\
\hline 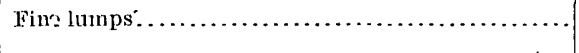 & 100 & 99 & 80 & 10 \\
\hline
\end{tabular}


Two methods of drying sand are in common use-the rapid method, effected by means of rotary cylindrical dryers, which operate on a principle similar to that applied in cement mills, and the slower method of allowing the sand to settle through coils of steam pipes. In the rotary driers the cylinder is slightly inclined to the horizontal; damp sand is fed in at the higher end and, aided by gravity, moves gradually toward the lower end of the cylinder. Heated and incandescent gases are forced into the cylinder, the interior of which may be fitted with an angle iron that lifts and drops the sand alternately, thus exposing it more completely to the action of heat. There is some objection to this method on the ground of overheating the sand and the consequent danger of its setting fire to the bins. If the heat is properly regulated, or if bins are of fireproof material, the danger is minimized, and since drying is completed in from five to ten minutes great economy of time is eflected-an essential feature where a large output is desired. Fuller discussion of methods of obtaining and preparing sand will be found in the descriptions of individual plants under the head "Details of sand properties," below.

In the accompanying tables are given the chemical composition and physical properties of twelve sands from Arkansas, Missouri, Kansas, and Wisconsin. These sands have attracted attention, either by their purity and general fitness or by their proximity to manufacturing centers. Direct comparison with sands of proved value can be made by reference to corresponding tables in the paper "Requirements of sand and limestone for glass making," pages $452-458$ of this bulletin.

\section{DETAILS OF SAND PROPERTIES.}

\section{ILLINOIS.}

The glass-sand industry in Illinois is mainly centralized in Lasalle County, along Illinois and Fox rivers near their junction. Topographic maps of Lasalle and Ottawa quadrangles, comprising this area, are issued by the Survey. The St. Peter sandstone, which is the rock utilized, has been exposed in this aren as the result of erosion across a low anticlinal fold, the axis of which passes northwest and southeast about 2 miles below Utica. The lowest rock exposed along the axis of this fold is a magnesian limestone containing natural cement-rock beds. It lies just below the St. Peter sandstone and is exposed along Illinois River Valley for about 3 miles below Utica. The dips on the west limb of the anticline are very marked near the axis, but to the east they are more gentle, and in both directions the dip flattens out so as to become imperceptible. Illinois River flows in a broad, flat, rock-bottomed valley with precipitous sides, and below the rock floor of the valley the stream has cut its present channel from 20 to 30 feet in depth. As a consequence of the steep westward dip, which occurs about $1 \frac{1}{2}$ miles east of Lasalle, the extent of the St. Peter sandstone on the west limb of the anticline is limited to a few hundred yards. Northward beyond the river valley the sandstone forms the country rock over several townships. Eastward from Utica to Ottawa the broad Illinois Valley is cut. in the flatlying sandstone, as is the narrower valley of Fox River, to a point above Wedron. Limestones of Carboniferous and occasionally of Trenton age overlie the sandstone along the valley bluffs. Transportation facilities are extremely favorable, since two railroads traverse the valley at Ottawa, and this advantage, together with the inexhaustible quantity of very, pure sand easily obtained, has brought the production of silica into prominence among the activities of the Illinois Valley.

Ottawa.-The Ottawa Silica Company's property lies about $1 \frac{1}{2}$ miles west of town, near the Illinois and Michigan Canal. This company operates two mills, about one-half mile apart, each mill deriving sand from an open pit sunk below the level of the valley bottom. The St. Peter sandstone lies horizontal and is everywhere near the surface throughout this portion of the valley. At these quarries a few inches to 3 feet of soil and glacial débris have been scraped away, laying bare the old waterworn and potholed surface of the sandstone. At the sides of the valley the formation rises 30 to 50 feet above the valley floor, and drilling is reportea to have shown the deposit to extend 280 feet below it, so that its total 
thickness is probably in excess of 300 feet. At the quarries of the Ottawa Silica Company only 60 feet of sand are worked at present on account of henvy ground water encountered at that depth. The sand is mostly massive, and is frequently cross-bedded. It is pure white and free from clay where freshly exposed in these two quarries, but the water that flows from the lower portion of the pits leaves a strong iron stain. Being very friable, the sindr cone breaks down almost completely in blasting, and the loose sand is washed down by a stream from a small nozzle, through a screen, into a pump. This pump forces the water and sand through a 6 -inch pipe along the quarry bottom to an elevator, which carries the wet sand up into the mill. Here the sand is washed twice, dried, and screened and is ready for shipment. The prepared sand is perfectly white and consists of well-rounded waterworn grains averaging conrser than sands from the other States mentioned in this article. Sand of different degrees of fineness is screened to order. The greater part of the product goes for glass making, although some is sold for furnace lining and for stone sawing. One thousand tons per day is the average output of these two mills.

On the south bank of Illinois River about 1 mile southeast of Ottawa is the plant of the United States Silica Company. The sand is quarried by the hydraulic process from sandstone outcropping at the surface near the top of the formation. In the pit first opened four or five clay pockets or holes, similar to buried wells, filled with clay were found. The new quarry has been sunk to 100 feet in one place, in order to get a good location for a water hole. Water, some of which is strongly mineralized, flows in below a depth of 75 feet, requiring the pumping of about 600 gallons per minute. This water is utilized in hydraulicking the sand. The depth of the sand beyond 110 feet has not been determined. The sand is cross-bedded and contains a few yellowish layers, in which the grains appear slightly coarser than the average. This yellowish sand, when friable, is mined with the rest, as the color nearly all washes out. Some layers are so hard that blasting does not break them up, but crushing has not yet been resorted to, as the supply of sand that can be hydraulicked is still very great. The sand is shot down and washed, by a stream of water under high pressure, into the sump of a Nye pump. Before entering the sump the sand passes through it three-eigh th-inch screen. It is raised by this pump to an air compressor, at present about 15 feet above the Nye pump. The air compressor has two tanks, which receive material alternately. The sand is raised to the imill by this compressor pump and run into bins or washers. From these washers the water which was raised with the sand is drained off into the river, then clean water is added, and the material is pumped into $\mathrm{a}$ second set of binsthe drain bins-24 in all. Here the sand stands about twelve hours, until the water is entirely drained off. From the drain bins the sand is shoveled out on driers. There are twelve driers, each consisting of five tiers of twenty 16-foot steam pipes. The bottom driers are closer together than the upper ones. The sand requires about fifteen hours 'for drying. It falls gradually through the driers onto a belt, which carries it to an elevator. From the elevator it goes through dry screens, and from the screens into storage bins. From the storage bins the sand is lowered into cars by elevating it to a delivery pipe. The best sand sold here is used for fine cut-glass ware and flint glass and bottles, the great bulk of it going to points in Indiana. Some, however, is shipped to Kansas and to Pennsylvania.

Utica.-Below Ottawa, along the Chicago, Rock Island and Pacific Railway, are a number of small sand banks producing mainly crude sand from the upper part of the St. Peter formation, but as Utica is approached the sandstone rises higher in the bluff, bringing the fine quality of sand into convenient position for quarrying. Two quarries--that of the Utica Fire Sand Company and that of E. J. Reynolds \& Co.-are situated respectively $1 \frac{1}{2}$ miles and one-half mile east of town. These firms produce mainly a good grade of sand, which is loaded directly on cars at the quarry without crushing or screening, but they also make glass sand, employing a hydraulic jet and pump to move the material down from the bluft to the mills.

Wedron.-The Wedron White Sand Company at this place, on Fox River, 7 miles above Ottawn, is a large producer of glass sand. An analysis of sand from Wedron is given on page 456 . 


\section{MISSOURI}

The belt of St. Peter ("Pacific") sandstone befween Klondike, on Missouri River, about 40 miles above its mouth, and Crystal City, on the Mississippi, 40 miles below St. Louis, contains the principal glass-sand plants of the State. This district is partially covered by the Survey topographic maps of the St. Louis, O'Fallon, and De Soto quadrangles. The rocks dip slightly to the northeast, but so slightly that locally they may be regarded as being horizontal. The outcrop of the sandstone in this region is from one-half mile to 5 miles wide. On the southwest the sandstone is bounded by older Ordovician dolomite and chert, while to the east it passes beneath later Ordovician dolomite, which is in turn overlain by Devonian and Mississippian limestone and shale. Mississippian and later strata constitute the country rock at St. Louis and beyond the river in Illinois, where they pass beneath the main areas of Pennsylvanian coal-bearing rocks.

Klondike.-Glass sand is produced at Klondike, on the north side of Missouri River about 40 miles above its mouth. The base of the St. Peter sandstone here is 80 or more feet above Missouri River, which flows close to the base of the bluff, just beyond the tracks of the Missouri, Kansas and Texas Railway. The sandstone is about 80 feet thick. It lies on an irregular surface of cherty magnesian limestone or dolomite, the uncomformity between the two formations being well displayed in the east pit of the quarry, where small domes of cherty rock extend up into the sandstone and coarse sandstone fills the hollows in the limestone floor. Overlying the St. Peter is a bed of soft greenish sand and clay shale, succeeded by alternating thin beds of sandy limestone, oolitic siliceous bands, clay shale, and earthy limestone, with more massive magnesian limestone beds above, the whole cover aggregating about 30 feet at the summit. This overlying formation has been termed the "First Magnesian" limestone. At present the removal of this overburden is a dead loss, since the rock is not considered of value for any purpose.

In texture the sandstone displays the well-known St. Peter characteristics of wellrounded, medium-sized grains (see table, p. 456) and is so friable as to be easily crushed. The upper 25 to 30 feet are slightly colored pink or brown in places. Lower down it becomes pure white or faint yellow. No marked cross-bedding is noticeable here, but in places there are distinct but not persistent horizontal bedding planes. Impurities are rare. Occasionally a small speck or "button" of iron oxide is encountered, cementing the adjacent sand grains into a very hard lump, but these harder masses are removed in screening. The workings of the Tavern Rock Sand Company àt Klondike extend about one-fourth mile along the face of the bluff. The sand is "shot" down and gathered by means of tram cars drawn by mules to central points in the several pits, where the cars are picked up by cable and drawn to the mill. The sand is dumped directly into crushers, from which it passes to the driers. It is elevated to the screens and then falls into bins, from which it is drawn off into railroad cars for shipment. There are twin mills built on the terrace capping the steep slope between the railroad track below and the base of the sandstone. Each mill is equipped with Gates gyratory crushers, rotary-drum driers, elevators, screens, bins, and chutes. The power house is on the river bank across the track from the mill. The position of the sand bed, high in the bluff, is of advantage in many ways. The quarries are easily drained and can be worked to the full thickness of the sandstone. While difficulties were encountered in the erection of the mill on the steep face of the bluft, its position in relation to the sandstone is of advantage, for gravity is made to play a large part in the process of handling the sand from the quarry to the railroad cars. The topography of the tract being worked by this company favors long continuance of the industry. When stripping of the beds overlying the sandstone has been carried as far as practicable on the river front, quarrying may be begun on the north side of the narrow divide which lies between the river and the small ravine parallel to it, about one-fourth mile to the north. After considerable quarrying has been done on the north side the thickest limestone cover in the middle of the ridge may be economically stripped back into the north quarry, making available the whole block of sandstone constituting the ridge back of Klondike and extending nearly one-half mile east. 
As the dip of the formation is to the northeast, the overburden presents an ever-increasing thickness in this direction, so that the eastward limit of profitable quarrying will be determined largely by this factor. As the sandstone in the upper 25 to 30 feet is slightly colored, it is usually kept separate from the whiter material below, which is prepared for glass making. The poorer grade of sand, after being crushed, dried, and screened, is sold mainly to steel foundries. An analysis of sand prepared for glass making from this quarry is given on page 456 . The daily output from this plant at the time of visit was about 16 cars of 30 tons each.

Becker.-At Becker, a station on the Chicago, Rock Island and Pacific Railway, on the south side of Missouri River, about 3 miles below Klondike, are sand quarries, now inactive, but formerly worked by the Tavern Rock Sand Company.

Grays Summit.-Nearly a mile northeast of the Missouri Pacific depot at Grays Summit, and 6 miles south-southeast of Klondike, is the plant of the White Sand Company of Missouri. Lying nearly in strike with the beds at Klondike, the St. Peter sandstone is here at a high elevation on the divide between the Missouri River drainage and that of the Meramec. The quarries of this company are located on the southeastern slope of the divide and are connected with the Missouri Pacific Railway by a spur. Seventy-five to 80 feet of the formation have been exposed by stripping and quarrying. The base is not exposed, but the top is overlain by the "First Magnesian" limestone. A total thickness of 167 feet was reported at this place, based on the measured thickness of the exposed portion plus a thickness noted in a drill hole. While the actual thickness could not be measured at the time of visit, it seems rather doubtful that the thickness of the formation should be doubled within 6 miles. However, it is obviously thicker at Grays Summit than at Klondike. The character of the sand shows no marked variation from that of the district in general. The color is uniformly white, except for faintly tinted bands, the rock from which is easily segregated and run separately through the mill, so that a product of uniform grade is insured. Some small lumps of iron oxide cementing the sand into concretions occur, but these are easily removed by screening. The sand is crushed, screened, and dried at this plant. The principle of operation is essentially the same as that employed at Klondike, but there are differences worth noting. After being "shot" down the sand is brought by tram cars to a 30 inch belt conveyer, which carries it into the mill on a level with the base of the quarry and empties it into a crusher. The crusber consists of thirty-two 20-pound hammers revolving 1,000 times per minute. A wet screen intervenes between the crusher and the revolving driers, which are heated directly by blast from coke as a fuel. After drying, the sand is once more screened before being stored. The sand from this plant is shipped mainly to glass factories, but it is sold for all other purposes for which sand is in demand. An analysis of a sample of crude sand from this plant is given on page 456.

Pacific.-For more than thirty years the shipping of sand has been one of the leading industries of Pacific, a town on both the Frisco and the Missouri Pacific railroads, about 35 miles west of St. Louis, and to the conspicuous occurrence of the St. Peter sandstone at this place is due the former name, "Pacific" sandstone. From beyond the western boundary of the town eastward for about one-half mile the sandstone is well situated for quarrying in the bluff along the northern edge of the Meramec River flood plain. It ranges from about 80 feet above the flood plain on the west to about 50 feet above the river at the easternmost quarry. Three firms are now producing sand at Pacific.

The Pacific White Sand Company has quarries, not now in operation, just north of the town, and its main active quarry is about $1 \frac{1}{4}$ miles east of the town. This quarry, on the bank of Meramec River, discloses massive beds of sandstone separated by distinct bedding planes. Along one such plane near the top of the quarry occurs a seam of yellowish fire sandy shale one-fourth to one-half inch thick, and this shale nppears also in the Frisco Railroad cut north of the quarry. Shale so rarely occurs in this formation that its presence here is worthy of note. It must be removed in the preparation of high-grade sand. In color the sand is mostly pure white, but striking variations are displayed, including shades of pink, light yellow to dark brown, and along $t$ :e bedding planes near the thin shale the 
sand is light green. The dark-brown layers are not utilized, but the fainter-colored beds are sometimes worked in with the white sand, as the color of the resulting mixture is scarcely perceptible. There is considerable variation in the hardness of the sandstone. Toward the top of the quarry the sand is loosest, as it has little or no cover. Through the middle of the quarry face, along bedding planes, run certain hard crusts, where the sand has been unusually cemented. This cementation occurs in the whitest sand, which otherwise would be most desirable to work. Segregations of quartzite, termed "niggerheads," also occur. One bed of light-brown sand, coarser grained than the average, sparkles in the sunlight, as it has undergone recrystallization. This sand is said to be higbly desirable for rock sawing, on account of its sharpness and coarseness. The sand is crushed, dried, and screened here. Cable and belt conveyors move the material, and drying is accomplished by steam coils, through which the sand gradually settles.

The quarries of the Missouri Silica Company are north of the railroad tracks, about threefourths of a mile east of the union station at Pacific. A large quantity of sand has been removed from the bluff here, and the quarry now presents a face 75 feet high by 400 feet long, capped by green sandy shale and overlying limestone. Near the top the sandstone is of a greenish color and is cross-bedded. At this quarry the sandstone is very soft and friable, breaking down under the influence of a heavy rain. This condition might render possible the hydraulicking of the deposit in a manner similar to that employed at Ottawa, Ill., particularly since a large pit at the bottom of the quarry is now filled with water, and under present conditions is a hindrance to the work. The best grade of sand is obtained from the lower part of the quarry, and is used for the finer grades of glassware and plate glass; the second grade, used for window giass and fine bottles, comes from the middle beds, while the upper material is suitable for colored bottles and for jars. The extent to which this deposit has been worked brings it near the limit of profitable stripping, unless new methods of working are stobstituted for those common to this locality. Some sand has been obtained by excavating caves into the bluff, but owing to the looseness of the sand this method can not be depended on here unless the sand is excavated completely up to the limestone roof.

The first quarry east of the union station, north of the track, at Pacific is operated by the Pacific Glass Sand Company. A face of some 60 feet of sand is being blasted down here and crushed, washed, dried, and screened at the mill. The sandstone extends below the quarry and may reach a totai thickness of 100 feet. The variations in color mentioned above are noticeable here, the colored sand running in strips and pockets. The greater part of the prepared sand from this plant goes to the works of the St. Louis Plate Glass Company, at Valley Park, Mo. The sand is subjected to two washings, which remove a small amount of "sediment," apparently a very fine clay, and also tend to reduce the color. Even after the second washing the sediment forms a thin film on successive layers of sand in the bins. The resulting color of the prepared sand is a very light yellow, imperceptible except in large masses. Plate glass made from it shows the usual pale-green tint on broken edges.

Crystal City.-Forty miles south of St. Louis, on the Frisco Railroad, at Crystal City; the plant of the Pittsburg Plate Glass Company is supplied with silica from its sand mines at that point. The St. Peter sandstone lies relatively low here, and only the upper 40 feet can be obtained by present methods. The openings are on the east side of a smail ravine that enters Plattin Creek from the southeast. The sandstone rises about 30 feet above the floor of this ravine. It is overlain by thin sandy shale, with medium beds of limestone above. In working the sand the overlying rock was first stripped back as far as practicable, or until a thickness of about 15 feet of the limestone was reached. Tunneling into the sandstone was then begun, and now five or six openings enter the bluff into connecting chambers, which have largely been mined out for about 100 feet, with the exception of the pillars. Other tunnels extend in one-fourth mile farther, and considerable sand has been removed all the way back. The floor of the openings is about 5 feet below the bottom of the ravine, but it has been impossible to mine much below this level on account of ground water. About 25 feet, vertically, of sand are removed, leaving 6 to 10 feet as roof. The 
sand has not been removed entirely to the top, on account of the impurity of the upper beds, but it seems that the overlying limestone might make a good roof after some of the lower shaly layers are pulled down. This method of mining is reported to be more expensive than opęn-pit workings, where stripping is necessary for only a few feet.

The sand appears in general rather uniform in color, but contains a few pale-yellowish strenks and is a trifle coarser than that from the quarries farther north. Several very white streaks near the top are somewhat harder than the rest, but as the ground level is approached the rock becomes more and more friable. The product for melting is crushed wished, and dried. An appreciable yellow sediment is removed by washing. Crushed but not washed sand is used in the factory for grinding and beveling plate glass. In this process the sand grains are made finer and finer, and the various grades are used successively, being finally replaced by emery powder and rouge in polishing. The quantity of sand in sight that may be won by the present process should be sufficient to supply the factory, with its proposed enlargements, for several years, since on the opposite side of the ravine little has been removed except from the tunnel through which the railroad spur reaches the mine. No sand is at present being shipped from here, however, presumably because of the cost of production. The friable condition of the sand below water level suggests that much of this material might be obtained by pumping it up into the mill.

Silica.-At this place also, 32 miles south of St. Louis, on the St. Louis, Iron Mountain and Southern Railway, is a large sand quarry in the St.Peter sandstone, where beds lower than those at Crystal City are reported to be worked.

\section{UNDEVELOPED RESOURCES.}

The St. Peter sandstone, the formation furnishing all the material now being exploited in the area here considered, has a very wide extent. It outcrops in the Mississippi Valley in the States of Minnesota, Wisconsin, Iowa, Illinois, and Missouri, and also around the flanks of the Ozark uplift in Missouri, Arkansas, and Indian Territory. Wherever it has been recognized it usually presents the same characteristics, viz, massive beds of very friable sandstone, having a total thickness ranging from 25 to possibly 300 feet, composed almost entirely of well-rounded, translucent quartz grains of slight variation in size. These features, so persistent throughout its extent, render it of value as a glass sand. Consequently, wherever this rock occurs it may contain the substance at least of a glass sand. Locally the sandstone has been observed to be badly. iron stained, also indurated to quartzite, both of which conditions render it of little value for glass making in comparison with the abundant unchanged material. In northern Arkansas the St. Peter formation has been found to contain a lens of dolomite, but even under this circumstance either or both the overlying and the underlying phases of sandstone may be of workable thickness. Aside from the St. Peter, there are other formations in this region containing beds of sand that, under certain conditions, may prove of value as glass material. Chief among these are Ordovician sandstones, older than the St. Peter, the Devonian and Carboniferous sandstones present in northwestern Arkansas and southwestern Missouri, the Buxton formation in the Independence and Fredonia quadrangles in southeastern Kansas, and the "Potsdam" or "Jordan" sandstone in the Wisconsin and Mississippi valleys in Wisconsin and adjoining portions of Iowa.

\section{MISSOURI.}

Southeast of Crystal City there is a good development of St. Peter sandstone, in Ste. Genevieve County, and at Jackson, Cape Girardeau County, the sand has been quarried. Samples from Jackson submitted to the office of the Survey are rather fine grained and friable and contain a small proportion of sharp or subangular grains. Some of the material is iron stained, and these portions are rather firmly cemented. (See item No. 12 in tables on. pp. 462-463 for properties.) Chemically this sand is well qualified for glass making, and while the sample submitted comes near the limit of fineness, screening would doubtless render it highly sạtisfactory. 
In southwestern Missouri, near Butterfield, Barry County, on the main line of the Frisco Railroad, is a deposit of sandstone, reported to be more than 36 feet deep, outcropping at the surface or lying below a few feet of soil. Three or four cars of sand have been shipped from this place.

\section{ARKANSAS.}

In the north-central and northwestern part of Arkansas, particularly along the valley of White River from Batesville nearly to Fayetteville, exposures of the St. Peter sandstone and Sylamore (Devonian) sandstone are common. Those deposits that face the river between Batesville and Cotter on the White River Branch of the Missouri Pacific Railway are in many places admirably situated for economical quarrying and transportation, and so far as a cursory examination would indicate they are of an excellent grade of glass sand. Survey publications relating to this region are as follows: Batesville, Mountain Home, Mountain View, Yellville, Eureka Springs, and Fayetteville topographic maps; Zinc and lead deposits of northern Arkansas (Prof. Paper No. 24), 1904, and Fayetteville folio (No. 119 of the Geologic Atlas of the United States), 1905. The sandstone mapped as "Key" in the Yellville quadrangle $a$ is frequently of suitable quality. Near Everton, on the east side of the valley of Clear Creek, is a bed 25 feet or more thick of good white saccharoidal sandstone, so situated that it will not require much stripping and also convenient to the railroad. Analyses of this sandstone appear on pages 462-463 (No.9), and show it to be of desirable quality. The Sylamore sandstone mapped in the Fayetteville quadrangle, $b$ along White River, is within 5 miles of the railroad at Rogers and adjacent to a railroad at Sulphur Springs.

KANSAS.

The topographic maps of the Iola, Fredonia, Independence, and Sedan quadrangles include the area here considered. The areal geology of the Independence quadrangle was mapped in 1904 by F. C. Schrader, who makes the following statement: $c$

In a number of localities along the western side of the Independence quadrangle, in the Buxton formation, sandstone occurring in bodies of from one-eighth to one-half mile in extent is of such purity fineness, and evenness of grain as to give promise of usefulness. in the manufacture of glass. The best quality occurs in heavy beds in which the rock has been least affected or stained by the leaching of descending surface waters. Exposures occur 4 miles northwest of Caney and 2 miles north of Caney. $\Lambda t$ the latter locality the long hill is capped by sandstone having a thickness of at least 10 feet. Other exposures pecur farther north. Perhaps the best is in the southern part of Fall River Township, in the SE. $\frac{1}{4}$ sec. 22, about 4 miles southwest of Fredonia. Here the rock is exposed over an area of 10 or 15 acres, and as nearly as can be judged from some local prospecting that has been done and from the topography, it is about 12 feet in thickness.

Samples of this rock were taken in October, 1905, from each of the above localities and were analyzed in the laboratory of the Survey, with the results, Nos. 1-8, page 462. Other exposures of the formation in the vicinity of Fredonia were also sampled.

At a point 2 miles north of Caney is a quarry on land of Mr. A. B. Cochran, leased by Mr. H. H. Lane, exposing the following section:

\section{Section of Buxton formation 2 miles north of Caney, Kans.}

5. Weathered brown sandstone, with a few feet of rocky slope above.

Ft. In.

4. Massive, rather firm, slightly micaceous, light-brown sandstone, separated from No. 3 by a joint plane ........................... 5

3. Massive, slightly friable, light-brown sandstone, with fine angular grains 5

2. Yellowish shaly sandstone, micaceous, very fine grained ............. 12

1. Massive soft sandstone, becoming harder on exposure. Angular quartz, with some chert grains and bands of iron rust................... 36

\footnotetext{
a Adams, G. T., Zine and lead deposits of northern Arkansas: Prof. Paper U. S. Geol. Survey No. 24, 1904, Pls. IV and $V$.

$b$ Geologic Atlas U. S., folio 119 , U. S. Gicol. Survey, 1905.

$c$ Economic geology of Independence quadrangle: Bull. U. S. Geol. Survey (in preparation).
} 
A drill is said to have shown sandstone to a depth of 8 feet below the base of the exposure. This would indicate $a$ total thickness of over 20 feet. In natural outcrops the rock is usually stained dark brown, and at this quarry a comparatively fresh exposure showed considerable discoloration; indicating that the material is deeply oxidized. Analysis No. 5 (p. 462) shows this sand to be fairly high in silica, but to contain too much iron to make anything but the conmonest jar and bottle glass, and the same may be said of sand from a point on the ridge west of Havana, near the county line (No. 6, p. 462). These sands are also slightly finer than is desirable, but this may be offset by the fact that the grains are mostly sharp. Two samples from near Niotaze (Nos. 7 and 8, p. 462) proved to be altogether too fine grained and rather low in silica. The high content of alumina is due to the micaceous character of the sandstone, a feature common to the sandstones of the region. It is probable, however, that sand at present under heavier cover would prove of slightly better composition throughout this locality. This could be economically determined by shallow drilling along the sandstone ridges in the vicinity of Caney, Havana, and Niotaze, and in view of the importance of developing low-grade glass sand it might be worth while to undertake it. One drill hole in each locality, if put down in solid rock, would determine the quality of the sand much more satisfactorily than openings along the face of a bluff.

Southwest of Fredonia, along the escarpment on the south side of Fall River, the sandstone is locally almost white, and such samples (Nos. 1 and 2, p. 462) on analysis proved to carry the least iron. This rock is not so friable as the St. Peter sandstone, but it can be mechanically crushed and its evenness and comparative sharpness of grain should render it satisfactory as a low-grade glass material. The chief considerations in regard to the practicability of opening up the deposit concern the outlay for equipment and trackage, since the best material lies about 4 miles from a railroad. The large investments in glass factories in southeastern Kansas indicate faith in a long life for the industry. With permanency assured to the business, even if the cost of production here were 100 per cent greater than in districts farther east, sand might be sold at a profit and still save money to the buyer. Other outcrops, where some prospecting has been done, were found to show about 20 feet of sandstone filled with more or less ferruginous spots. The best samplej that could be obtained here have been examined with results given under No. 4 (p. 462). From a bed of sandstone apparently near the base of the Buxton formation, $1 \frac{1}{2}$ miles southeast of Fredonia, a sample was taken, and its propertieś are given under No. 3 (p. 462). Only about 6 feet of a cross-bedded sandstone show here above the level of a small creek. The rock is a light-gray micaceous, porous, soft sandstone, with grains somewhat angular and a trifle coarser than is usual in sandstones of this vicinity. The rock has a sprinkling of specks of iron rust running through it. The total thickness could not be ascertained.

\section{WISCONSIN.}

In southwestern Wisconsin along Mississippi River and its tributaries, from a few miles above Dubuque, Iowa, nearly to Wisconsin River, the St. Peter sandstone is a persistent formation lying low in the valleys in the southwestern part of the area and rising to the tops of the hills toward the northenst. Where low in the section the sandstone is heavily covered by limestone and dolomite and in places is badly iron-stained, but in general it is protected from waters descending from the overlying formations by a bed of clay shale. The sandstone is usually so soft as to be worked with a pick and shovel, and it is quarried extensively for local uses, although it is by no means as sharp a sand as might be desired for building purposes. It would probably make a good glass sand, but in localities along Mississippi River near the Chicago, Burlington and Quincy Railroad, or near the Chicago, Milwaukee and St. Paul Railway on the Iowa side, where, situated close to transportation facilities, it is doubtful if it could be exploited except by mining. The distribution of the St. Peter sandstone has been mapped during the survey of the Lancaster and Mineral Point quadrangles, and the maps are expected soon to be available in the Lancaster-Mineral Point folio. Additional topographic maps that comprise outlying edges of this district 
are those of the Elkader, Waukon, and Richland Center quadrangles. Tests made of St. Peter sand from a point near Grant River south of Flora, Wis., indicate that its quality is all that could be desired as a glass material. (See No. 10, pp. 462-463.)

In the valley of Wisconsin River the "Potsdam" formation contains several valuable beds of clean quartz sand, rather coarse, well rounded, and loosely cemented. Exposures, probably of the "Jordan" sandstone horizon, occur in the bluffs near Boscobel, Wis., in close proximity to the Chicago, Milwaukee and St. Paul Railway. The properties of sand from this locality are given under No. 11 (pp. 462-463). The chemical composition is excellent and the sand is of very desirable size.

\section{GENERAL ASPECTS OF GLASS-SAND INDUSTRY.}

The consumption of glass sand has been rapidly increasing for many years, and it is probable that it will continue to do so indefinitely. Vast resources of the material are in sight. The uses for glass are now so varied and extensive that it may well be classed with iron and cement in its importance under present conditions. Glass sand in situ possesses relatively little intrinsic value. The market value is due to the labor cost of extraction and preparation.

The factors on which a deposit of sand depends for its possible value for glass making are (1) chemical composition, (2) physical character, (3) amount available, (4) location with respect to fuel supplies, (5) conditions of quarrying or mining, (6) location with respect to transportation routes, and (7) location with respect to markets. The first two have been treated rather fully in the foregoing pages.

A deposit so thin as 20 feet should have an areal extent of at least 20 acres of good sand in sight to warrant the erection of a mill and trackage. Most deposits are thicker than 20 feet, but it would be safer to have a much higher ratio between areal extent and thickness than the minimum given. Where ledges of sand require stripping of overlying limestone, the limestone may in certain cases be of such purity that it also could be used for glass making; if this is not the case other uses should be sought for it as a by-product. In regard to fuel, every plant turning out glass sand in quantity sufficient to net a profit must be equipped with power for moving the sand and drying it, and in most cases with equipment for cleaning it as well. The margin of profit is at present so low that the cost of preparation can not reasonably stand freight charges on coal for more than 50 miles. - Natural gas would be a suitable fuel, especially in the operation of rotary driers. In respect to transportation routes, the general principle "the more available the better" is applicable. Aside from the necessity of securing fair and uniform freight rates experience has shown, especially where the dependence is on only one railroad for transportation, that shortness of cars at certain seasons may seriously handicap a plant in its shipments and lead to cancellation of many orders. In respect to markets, it must be considered that sand is for its value one of the bulkiest products, and therefore one whose cost to the consumer is greatly influenced by distance. At the same time the question of permanence of these markets must be considered.

Some of the large sand properties, together with their mills, represent an outlay of about $\$ 75,000$, a sum that requires good business judgment for its investment and subsequent careful management in order to keep it paying adequate interest. Strong competition in the Middle States has forced prices down very low at present, and competition in the form of the small producer who leases a sand bank and works out by hand and team all the choice sand within convenient distance and then abandons the quarry, having figured only daily wages to himself as profit, has resulted in some embarrassment to the larger companies. 


\title{
THE GLASS-SAND INDUSTRY IN EASTERN WEST VIRGINIA.
}

\author{
By Georgie W. Stose.
}

The deposits of pure quartz sandstones occurring between Hancock, Md., and Berkeley Springs, W. Va., have been quarried for many years, but it is only within the past few years that mining operations have become active.

Geology.-The sand is derived from a white sandstone composing the Warm Spring Ridge in West Virginia, which runs south-southwest from Potomac River opposite Hancock, Md. This formation is the Oriskany sandstone and is part of a monoclinal series of beds between a massive anticline bringing up Medina sandstone in Cacapon Mountain, $1 \frac{1}{2}$ miles to the west, and a sharp syncline of Carboniferous rocks forming Sleepy Creek Mountain, 6 miles to the east. The rocks strike N. $10^{\circ}-25^{\circ} \mathrm{E}$. and dip $50^{\circ} \mathrm{SE}$. On the west, beneath the sandstone, are limestones of Helderberg age and shales of Cayuga age. Above it, on the east flank of the ridge, is a belt of black shales of Marcellus and Hamilton age, followed by Chemung rocks.

Character of the sand rock.-The sandstone of this ridge is of exceptional purity. In other outcrops of this formation to the east and west, where it is brought to the surface by folding, it is commonly a siliceous limestone with chert nodules and fine conglomerate. The pure sand rock seems to be limited to a few miles in length along the strike of the Warm Spring Ridgè, for northward in Maryland it changes to a yellow, impure, and coarse sand rock, suitable only for building sand. Its extent southward has not been determined. It is mined as far as Berkeley Springs, the end of the railroad spur up the Warm Spring Valley, but the same character of rocks at the surface seems to continue far beyond, and the land is held largely as sand land, its development awaiting the extension of the railroad.

This pure white quartz sand is evidently a beach or near-shore deposit, and its purity, freedom from mud and other fine detritus, the uniform size of its particles, and their subrounded character indicate long-continued sorting action at this part of the shore. The grains are of medium fineness, practically all passing a 40 -mesh sieve and 25 per cent passing a 60 -mesh sieve. Particles of milky cryptocrystalline silica are scattered among the grains; whether these are original chert fragments or were deposited there from solution is not known. The grains are loosely cemented by lime, the Berkeley Springs water, which issues from the upper beds of this formation, containing a small percentage of carbonate of calcium. At the surface the rock is hardened and slightly glazed, apparently by the solution and redeposition of silica between the grains. In depth, however, the rock is commonly soft, breaking into grains in blasting or by the use of the sledge hammer.

Pennsylvania Glass Sand Company.-The oldest mine, located near the north end of the ridge, is operated by the Pennsylvania Glass Sand Company. The mine is but 2 miles from Hancock. It is located on the top of the ridge, where the edges of the sandstone beds outcrop in rocky ledges 300 feet above the Baltimore and Ohio Railroad track along the river at the west foot of the ridge. This mine was established before the branch railroad up the Warm Spring Valley was built, and the only direct railroad communication was by the main line to the west. The western side of the ridge is composed of Helderberg limestone, through which a tunnel had to be constructed to reach the sandstone on the eastern side, The mine is a large open cut, 120 feet deep, about 130 feet wide, and 400 feet long. At its south end is a tunnel in which much rock has been quarried, but this method of mining has been abandoned and the whole width of the ledge is now being worked as an open cut: 
About 150 feet of rock are exposed in the quarry and most of this is available for glass sand. The total thickness of the formation is probably about 170 or 180 feet. The upper part is a hard bed 20 feet thick which is not mined, but is used as the east wall of the hole. On account of the steep eastward dip it overhangs and is to some extent a source of danger, as in places it has caved in. The sandstone as quarried varies from pure white to creamy and is generally fine grained with an occasional coarse bed. Below the surface it crumbles on being quarried and the sand is handled largely by shovel. Large lumps are readily broken with a sledge hammer, and the few masses from harder beds which do not yield to this treatment are thrown aside and not utilized, as this company does not use a rock crusher. The rock is drilled by steam, the power plant being located on the old floor of the quarry on the level of the tramway tunnel. The quarry has since been carried 30 feet below this level, which necessitates a cable tram to hàu the loaded cars to the grade of the tunnel. On account of the inclosed character and the depth of the quarry the heat becomes unendurable in the summer, and a canvas awning is suspended over the workmen to shield them from the sun.

From the mouth of the tunnel 200 feet above the railroad a narrow-gage railroad runs to the mill at the river, three-fourths of a mile north. The grade on this tramway is sufficiently gentle for mules to haul the empty cars over it, but recently a small locomotive was installed. At the mill the sand and rock are passed through a roller or mull and then wasbed and dried, the product being a pure white quartz sand, suitable for making table, window, and plate glass. The capacity was reported to be 200 tons a day. The mill was destroyed by fire early in 1905 , but has since been rebuilt.

The other mines on this ridge are all located on the eastern flank along tine Warm Spring Valley. The construction of the Berkeley Springs Branch of the Baltimore and Ohio Railroad from Hancock to Berkeley Springs made the eastern part of the Warm Spring Ridge accessible to the railroad and was the cause of the recent rapid development of the mining industry. Two companies began operation about the same time, the Berkeley Springs Sand Company and the West Virginia Sand Company.

Berkeley Springs Sand Company.-This company opened a mine at the northern edge of the town of Berkeley Springs. This is the southernmost opening on the ridge. The quarry, like all those on the eastern side of the ridge, is midway on the slope, about 150 feet above the valley bottom, and near the base of the sandstone exposure. It is an open cut 200 feet long by 100 feet across and 50 or 60 feet deep. It is entered by a short tunnel through the harder cap rock forming the eastern face, which is not quarried here. The rock appears to be of excellent quality and has furnished a high grade of sand. A cable tramway leads to the mill in the valley. The mine was shut down during the writer's visit in 1904, and its capacity was not determined.

West Virginia Sand Company.-The first mine operated by this company is located onebalf mile north of the quarry of the Berkeley Springs Sand Company. In 1904 it opened a second quarry and mill, adjoining the first. These quarries are 200 feet above the valley. The older opening was about 100 feet square, exposing throughout white rock somewhat harder than that at the Pennsylvania Company's mine. The cap rock is hard, coarse, and somewhat impure, but is mined and, together with 10 feet of surface stripping and weathered streaks where the sand is stained yellowish, makes a second grade of sand, used for bottle glass and railroad sand. Ninety per cent of the rock produces sand of No. 1 grade, pure white, and containing over 98 per cent of $\mathrm{SiO}_{2}$. This is used for plate and window glass and tableware. The very choicest is reported to run 99.8 per cent $\mathrm{SiO}_{2}$ and is used for the finest cut glass.

The stone is drilled by compressed air and is brought to the mills in the valley by two double-track gravity cable tramways. The material is assorted at the quarries and the surface rock and other second-grade material is sent to the old mill for treatment. The better grade rock is taken to the new mill on elevated tracks and dumped into chutes which lead directly to two mulls, the larger fragments being first sorted out and run through a Blake 、 crusher. In the mulls, which are circular vats in which revolve two heavy iron wheels at 
the ends of an axle, it is crushed wet, until it will pass through a fine screen into the washers. These consist of long inclined boxes in which large screws revolve, and the sand is churned and cleaned as it is carried upward by the screw against a flood of water down the box. The tailings are deposited in settling yards and make good building sand. The washed sand is conveyed by horizontal continuous belts to the drying room or to temporary bins on the way. The drier is a slowly revolving inclined cylinder over a fire box. The hot, dry sand is delivered at the lower end into cups of an endless chain, which carry it out of the building to elevated iron storage tanks on concrete piers, ready for loading by gravity. Every precuution against fire is taken in this modern plant, since the former mill was destroyed by fire from overheated sand deposited in wooden bins. The capacity of the two mills is 10 carloads of 30 ton a day, and the average shipment is reported to be 6 cars.

In the summer of 1905 the same company opened two new quarries and was erecting two new mills within a mile of the old quarries, and the company is said to have bought up all the property between the Berkeley Springs mine and the Pennsylvania mine, except a small area known as the Spear property, which was opened in 1905 by an independent company.

In the town of Berkeley Springs a pulverizing mill is operated by the National Milling and Mining Company, which is under the same management as the West Virginia Sand Company. Some of the highest grade of sand is pulverized at this mill for use in porcelain, china, and glazed-brick manufacture.

Silica Sand Company.-In 1904 a sand mine was opened on the west side of Cacapon Mountain, $1 \frac{1}{2}$ miles west of Berkeley Springs. This mountain is composed of Medina sandstone, the core of the massive anticline previously referred to. The opening is along the Berkeley Springs-Great Cacapon road, on the west crest of the ridge, and is owned by the Silica Sand Company, of Pittsburg, Pa. A hole 20 feet wide and 150 feet long had been quarried into the face of the hill, exposing low westward dipping beds of hard quartzitic sandstone somewhat stained with iron. The quarry is admirably located for handling the product by gravity 500 feet down the slope, on a grade of about $70^{\circ}$ to the railroad. At the bottom of the incline a mill has been constructed with the different compartments arranged in terrace form, utilizing gravity in crushing, washing, drying, and storing the product ready for loading on the cars. So far as the writer knows, however, the plant has not been in practical operation.

The rock is so hard, even at the depth attained, that it must all be crushed and thoroughly ground, and even then it does not separate into grains, but breaks into fragments of various sizes, much being reduced to a powder. The product, therefore, is not so suitable for high-grade glass, and the greater amount of grinding necessarily adds to the cost of production. The surface appearance of the rock is also not favorable, as it has a grayish cast with numerous iron stains, but an analysis was not obtained and its exact composition is not known. The successful operation of this mine, although so admirably situated for a gravity plant, is very dubious on account of the character of the rock, and further mining on this outcrop is not to be encournged.

Other sand quarries.-At Hancock, on the Maryland side of the river, the Warm Spring Ridge sand rock is quarried, but is coarse and impure and furnishes only a low grade of yellow sand for building purposes. This was extensively used by the Western Maryland Railroad in the concrete work along its new extension to Cumberland. A similar building-sand quarry is located opposite Great Cacapon, W. Va., 8 miles up the river, where the same Oriskany sand rock outcrops on the other side of the Cacapon Mountrin anticline mentioned above. This rock appears to be of better grade than that at Hancock, but is much harder. The product was largely used in the construction of the same railroad. 